\title{
Identification of a stem cell candidate in the normal human
}

\section{prostate gland}

\author{
Monika Schmelz ${ }^{a, b},{ }^{*}$, Roland Moll $^{c}$, Ulrike Hesse ${ }^{c}$, Anil R. Prasad ${ }^{a, b}$, Jay A. Gandolfi ${ }^{d}$, Shirin \\ R. Hasan ${ }^{e}$, Marty Bartholdie, and Anne E. Cress ${ }^{f}$ \\ aDepartment of Pathology, Southern Arizona Veterans Affairs Health Care System, 3601 S. 6th \\ Ave., Tucson, AZ 85723, USA \\ ${ }^{b}$ Department of Pathology, University of Arizona Health Sciences Center, 1501 N. Campbell Ave., \\ Tucson, AZ 85724, USA \\ CInstitute of Pathology, University Clinics, Philipp University of Marburg, Baldingerstrasse, D-35033 \\ Marburg, Germany \\ dDepartment of Pharmacology and Toxicology, College of Pharmacy, University of Arizona, 1501 \\ N. Campbell Ave., Tucson, AZ 85721, USA \\ eApplied Imaging Corp, 120 Baytech Drive, San Jose, CA 95134-2302, USA \\ ${ }^{\dagger}$ Arizona Cancer Center, University of Arizona, 1515 N. Campbell Ave., Tucson, AZ 85724, USA
}

\begin{abstract}
Stem cells of the human prostate gland have not yet been identified utilizing a structural biomarker. We have discovered a new prostatic epithelial cell phenotype-expressing cytokeratin 6a (Ck6a+ cells). The Ck6a+ cells are present within a specialized niche in the basal cell compartment in fetal, juvenile and adult prostate tissue, and within the stem cell-enriched urogenital sinus. In adult normal prostate tissue, the average abundance of Ck6a+ cells was $4.9 \%$. With proliferative stimuli in the prostate organ culture model, in which the epithelial-stromal interaction was maintained, a remarkable increase of $\mathrm{Ck}$ 6a expression was noticed to up to $64.9 \%$. The difference in cytokeratin 6a expression between the normal adult prostate and the prostate organ culture model was statistically significant $(p<0.0001)$. Within the prostate organ culture model the increase of cytokeratin 6aexpressing cells significantly correlated with increased proliferation index $(r=0.7616 ; p=0.0467)$ The Ck6a+ cells were capable of differentiation as indicated by their expression of luminal cell markers such as ZO-1 and prostate specific antigen (PSA). Our data indicate that Ck6a+ cells represent a prostatic epithelial stem cell candidate possessing high potential for proliferation and differentiation. Since the development of benign prostatic hyperplasia and prostate carcinogenesis are disorders of proliferation and differentiation, the Ck6a+ cells may represent a major element in the development of these diseases.
\end{abstract}

\section{Keywords}

Prostate; Glandular epithelium; Stem cells; Cytokeratin 6

\footnotetext{
(C) 2005 Elsevier GmbH. All rights reserved.

*Corresponding author. Southern Arizona Veterans Affairs Health Care System, Department of Pathology (6-113), 3601 S.6th Ave, Tucson, AZ 85723, USA. Tel.: +1 520792 1450x6882; fax: +1 520629 1756. E-mail address: monika.schmelz@med.va.gov (M. Schmelz).
} 


\section{Introduction}

Benign prostatic hyperplasia (BPH) and prostate cancer, both disorders of cell differentiation and cell proliferation, are major causes of morbidity and mortality in elderly men. Androgens are required for normal prostatic development and tissue homeostasis (Isaacs, 1987; Hayward et al., 1996a, b). Evidence for the existence of prostatic epithelial stem cells came from experiments in rats. Following castration, the androgen-deprived adult prostate underwent rapid atrophy with loss via apoptosis of up to $90 \%$ of predominantly luminal epithelial cells (English et al., 1985, 1987; Hayward et al., 1996b; Rouleau et al., 1990). The cells that remained were androgen independent with some of them being androgen responsive. Upon restimulation with androgens the regressed prostate gland completely regenerated (Isaacs, 1987).

Presumably, a reservoir of androgen-receptive stem cells accounted for the regeneration of the prostate.

A stem cell -driven hierarchical mechanism for routine prostatic epithelial renewal has been postulated (Bonkhoff et al., 1994; Bonkhoff and Remberger, 1996; Isaacs and Coffey, 1989). There is evidence that the expansion and/or neoplastic transformation of epithelial stem cells is the cause of BPH and/or prostate cancer (Isaacs and Coffey, 1989; Schalken and van Leenders, 2003). Therefore, the immunophenotypical characterization of prostatic stem cell candidates will contribute to immunotherapeutic targeting and prophylactic strategies for treating prostatic diseases.

During prostate morphogenesis small solid glandular buds are formed by outgrowth of epithelial cells from the stem cell-rich urogenital sinus. These buds intrude into the stroma to form complex branched ductal prostatic structures. One hypothesis about the initiating event in BPH, and possibly the beginning of neoplastic transformation, suggests that glandular budding and branching may be reactivated in the adult prostate (McNeal, 1978, 1988). Such reactivated branching activity was demonstrated in the adult prostate (Xue et al., 2001).

The normal prostate shows a high degree of cellular organization with two distinct compartments, the basal and the luminal layer. Exocrine, terminally differentiated luminal cells, express cytokeratin 18 (Sherwood et al., 1990) and PSA, and show androgen dependence. Basal cells express cytokeratin 5 and are androgen independent. Neuroendocrine cells are dispersed throughout these two layers. This cytokeratin expression pattern can change with the degree of cellular differentiation and the compartmental location (van Leenders et al., 2000; Xue et al., 1997). An intermediate cellular phenotype expresses both, basal and luminal cytokeratins (Bonkhoff et al., 1994; Verhagen et al., 1992).

According to one hypothesis for adult prostatic epithelial tissue homeostasis, a small uncommitted basal stem cell subpopulation gives rise to a new generation of uncommitted stem cells along with a more committed transiently proliferating/amplifying (TP/A) cell population (Bonkhoff and Remberger, 1996; Bui and Reiter, 1999). These intermediate TP/A cells, which are androgen responsive, express cytokeratin 5 and 18 (van Leenders et al., 2000) and give rise to both exocrine and neuroendocrine cells (Xue et al., 1997). Cytokeratin 19, which has been implicated in the differentiation of many different epithelial tissues, was also associated with an intermediate, amplifying non-stem cell population in the prostate (Hudson et al., 2001).

Putative prostatic stem cell characteristics defined by stimulated gene products such as the expression of pp32, prostate stem cell antigen, pi class glutathione S-transferase (GSTP-1), and p63 have been described (DeMarzo et al., 1998; Moskaluk et al., 1997; Reiter et al., 1998; Walensky et al., 1993). Also higher levels of telomerase and $\alpha 2$-integrin co-expressed with CD 133, and low levels of $\mathrm{p}^{27 \mathrm{kip}^{1}}$ have been ascribed to prostatic stem cells (Collins et al., 2001; Paradis et al., 1999; Richardson et al., 2004; Sherr, 1996). The present work 
complements these previous studies by identifying a new structural marker for uncommitted stem cells in vivo.

The aim of this study was to identify prostatic cell subpopulations with proliferation and differentiation potential. The members of the cytokeratin 6 family are structural proteins associated with hyperproliferation and aberrant differentiation as seen in psoriasis and certain types of cancer (McGowan and Coulombe, 1998). An increased cytokeratin 6 expression occurs in keratinocytes at the edge of skin wounds (Takahashi et al., 1998). We tested cytokeratin 6 expression in vivo as a structural marker to identify prostatic stem cell candidates. We then tested these stem cell candidates for the following criteria: occurrence in specialized compartments consistent with "niche-like" stem cell distributions in fetal, juvenile and adult prostatic epithelium, differentiation potential, expansion and proliferation potential.

\section{Materials and methods}

\section{Clinical material}

For this study, we analyzed human normal prostatic glands, as defined by the presence of basal cells with no relevant BPH, from 46 adult males. Forty-one specimens were obtained from radical prostatectomy from patients diagnosed with prostatic adenocarcinoma, and five were prostates, which were resected from patients with bladder cancer. In addition, we analyzed 16 human juvenile prostates prior to pubertal stimulation (age range: 1 month-12 years, one stillborn), and eight human fetal autopsy specimens (gestation weeks 22-39). The tissue material was collected with IRB approval (Assurance of Compliance HSC.A03.50) as described previously (Schmelz et al., 2002). The fresh tissue was snap-frozen or formalin-fixed and paraffin embedded. The frozen tissues were stored at $-80{ }^{\circ} \mathrm{C}$.

\section{Cell culture}

For isolation of prostatic primary epithelial cells, single pieces of prostate tissue $(\sim 5 \mathrm{~mm} \times 5$ $\mathrm{mm}$ ) containing basal cells, which were obtained from radical prostatectomies, were placed in culture dishes in IMDM (Irvine Scientific, Santa Ana, CA) with 10\% FBS (ATLANTA Biologicals, Norcross, GA), $100 \mathrm{U} / \mathrm{ml}$ penicillin G (Irvine Scientific), $100 \mu \mathrm{m} / \mathrm{ml}$ streptomycin sulfate (Irvine Scientific), and $2 \mathrm{mM}$ L-glutamine and cultured in a $5 \% \mathrm{CO}_{2}$ humidified atmosphere at $37{ }^{\circ} \mathrm{C}$ on coverslips for immunocytochemical analysis or on plastic dishes for biochemical analysis. After $\sim 1$ week of culture, outgrowth of epithelial cells was observed. The culture medium was refreshed twice a week. After $\sim 3$ weeks of culture when a confluent monolayer was formed, the primary epithelial cells were processed (passage 0 ) for either immunocytochemistry or biochemistry.

Other cell culture lines in this study included human keratinocytes HaCaT (kindly provided by Dr. N. Fusenig, German Cancer Research Center, Heidelberg, Germany), and K562, a human erythroleukemia line (American Type Culture Collection, Rockville, MD).

\section{Prostate tissue organ culture}

Cores of $\sim 1.5 \mathrm{~cm}$ length ( $\sim 6 \mathrm{~mm}$ diameter) were taken from normal human prostate tissue which was obtained from radical prostatectomies. We generated precision-cut slices $(270-300 \mu \mathrm{m}$ thick) from these tissue cores using the Brendel-Vitron tissue slicer (Vitron, Inc., Tucson, AZ), as described previously (Parrish et al., 2002). The slices then were cultured up to $72 \mathrm{~h}$ in a rotating organ culture incubator $\left(95 \% \mathrm{O}_{2} ; 5 \% \mathrm{CO}_{2}\right.$ at a flow rate of $\left.1 \mathrm{ml} / \mathrm{min}\right)$ in keratinocyte basal medium with $10 \%$ fetal calf serum, $50 \mathrm{U} / \mathrm{ml}$ gentamycin, $100 \mathrm{U} / \mathrm{ml}$ penicillin G/ streptomycin, and $0.625 \mathrm{mg} / \mathrm{ml}$ fungizone (Gibco, Grand Island, NY). The culture medium was changed every $24 \mathrm{~h}$. The slices then were either snap-frozen in isopentane cooled in liquid nitrogen and stored at $-80{ }^{\circ} \mathrm{C}$, or fixed in $10 \%$ formalin followed by embedding in paraffin. 


\section{One- and two-dimensional SDS-PAGE and immunoblotting}

The outer root sheath tissue was prepared from freshly plucked human scalp hair follicles of one of the authors by stripping off the root sheath from the hair shaft using a fine forceps. Stratified squamous epithelium of human vagina (autopsy specimen) was prepared by microdissection from $20 \mu \mathrm{m}$ thick cryostat sections under microscopic control, and cytoskeletal fractions were subsequently prepared as described previously (Moll et al., 1982; Achtstätter et al., 1986). Tissue proteins, to which 3-phosphoglycerokinase (PGK) had been added as marker protein, were separated by two-dimensional gel electrophoresis, using non-equilibrium $\mathrm{pH}$ gradient (NEPHGE) electrophoresis in the first dimension and SDS-PAGE in the second dimension followed by immunoblotting (Achtstätter et al., 1986). Bound primary antibody KA12 (see below) was visualized by incubation with secondary peroxidase-conjugated rabbit antibodies against mouse immunoglobulins (Dako, Hamburg, Germany) and, after washing, by subsequent staining with a 3,3'-diaminobenzidine (DAB) solution in PBS containing $\mathrm{H}_{2} \mathrm{O}_{2}$ and $0.015 \%$ nickel-II-sulfate. After photographic documentation, the nitrocellulose membranes were stained with india ink to reveal all proteins present and rephotographed.

For one-dimensional SDS-PAGE, total protein fractions were prepared from cultured cells by rinsing the cells quickly in cold PBS containing protease inhibitors (protease inhibitor tablets, Complete $^{\mathrm{TM}}$, Roche Molecular Biochemicals, Indianapolis, IN) followed by suspension in gel electrophoresis buffer (125mM Tris-HCl, 20mM DTT, $1 \%$ SDS, $10 \%$ glycerin, 2mM EDTA, $\mathrm{pH}$ 6.8). After SDS-PAGE, proteins were immunoblotted and further processed as described elsewhere (Achtstätter et al., 1986). For detection of bound primary antibody KA12 in the onedimensional immunoblot, horseradish peroxidase-conjugated goat anti-mouse secondary antibodies (Jackson ImmunoResearch Laboratories, Inc.) were used in combination with the enhanced chemiluminescence system (Amer-sham Pharmacia Biotech, Inc. Piscataway, NJ).

\section{Antibodies}

The anti-cytokeratin 6a mouse monoclonal antibody KA 12 was kindly provided by Dr. R. Nagle (Arizona Cancer Center, University of AZ, Tucson, AZ). In brief, for the generation of anti-cytokeratin 6 (clone KA 12) antibodies, keratins were isolated from human foot sole epidermis using the salt extraction method described by Sun and Green (1978). Immunization and the production of monoclonal antibodies against cytokeratin 6a (clone KA12) were performed according to standard protocol (Nagle et al., 1985). For this study, we further used the following murine monoclonal antibodies: anti-cytokeratin 5 clone KA 2 (Fan et al., 1997); anti-human cytokeratin 19 conjugated to FITC (Abcam Ltd., Cambridge, UK). The guinea pig polyclonal antibody specific to recombinant cytokeratin 5 was from Research Diagnostics, Inc. (Flanders, NJ). Rabbit polyclonal antibodies were purchased: antichromogranin A, anti-human Ki 67, and anti-ZO-1 (Zymed Laboratories, Inc., San Francisco, CA), and anti-PSA (Dakocytomation California Inc., Carpinteria, CA). The rabbit antibodies specific for the $\alpha 2$ subchain of laminin 5 and the murine antibody against collagen VII (clone 9C3) were kindly provided by Dr. J. Jones (Northwestern University, Chicago, Il). The generation and purification of the rabbit polyclonal antibody $18 \mathrm{~A}$, which reacts mainly with cytokeratin 5 and 14 but also with cytokeratins 8 and 18, was described by Nagle and coworkers (Nagle et al., 1985). The secondary antibodies we used for immunofluorescence microscopy were Alexa Fluor 568 goat anti-rabbit IgG, Alexa 488 and 350 goat anti-mouse $\mathrm{IgG}$, and Alexa 488 anti-rat IgG (Molecular Probes, Eugene, OR).

\section{Confocal laser scanning microscopy}

For immunofluorescence microscopy, frozen prostate tissue or tissue slices from the organ culture were fixed for $10 \mathrm{~min}$ in $-20^{\circ} \mathrm{C}$ acetone and air-dried. Primary antibodies were applied for $30 \mathrm{~min}$, followed by three $5 \mathrm{~min}$ PBS washes, before application of secondary antibodies for $30 \mathrm{~min}$. After antibody binding, specimens were then washed again in PBS, rinsed briefly 
in water and then fixed in ethanol for $5 \mathrm{~min}$, air-dried, and mounted. For visualization of nuclei, sections were incubated with a $1 \mu \mathrm{g} / \mathrm{ml}$ solution of bisbenzimide $\mathrm{H} 33258$ fluorochrome (Calbiochem, La Jolla, CA).

Double-stainings were analyzed using a Zeiss LSM 410 UV confocal laser scanning microscope (Carl Zeiss, Oberkochen, Germany). For double-label fluorescence, an argon/ krypton ion laser operating at 488 and $568 \mathrm{~nm}$ was used together with a long-pass filter 590 for visualization of Alexa 568 fluorescence and a band-pass filter 515-540 for visualization of Alexa 488 fluorescence. RGB images were taken in high-resolution mode using $1024 \times 1024$ image points (pixels) and $8 \mathrm{~s}$ scan time. Noise levels were reduced by line averaging of the scans.

Triple-stainings were viewed with an Axiovert 200 (Carl Zeiss) fluorescence microscope equipped with a bandpass filter for optimal 568-488-350nm wavelengths separation, and a Coolview 12 cooled charge-couple device $(C C D)$ camera $(1024 \times 1024,12$ bit pixels; Zeiss AxioCAM camera) controlled by Axiovision 3.0 software (Carl Zeiss). The image obtained with each antibody was stored separately as a data file. To generate the corresponding multicolored images, files were merged using Adobe Photoshop (v5.0; Adobe Systems, San Jose, CA). Immunohistochemical images were acquired using ARIOL-SL 50 (Applied Imaging Corp., San Jose, CA).

\section{Electron microscopy}

For conventional transmission electron microscopy, prostatic tissue slices grown for $48 \mathrm{~h}$ in the prostate organ culture model were rinsed in pre-warmed PBS followed by $1 \mathrm{~h}$ fixation in $3 \%$ glutaraldehyde in $100 \mathrm{mM}$ sodium cacodylate buffer ( $\mathrm{pH}$ 7.2). After brief washes in ( $3 \times$ $10 \mathrm{~min}$ ) the tissue slices were postfixed in $2 \% \mathrm{OsO}_{4}$ (same buffer) for $1 \mathrm{~h}$ on ice, washed with buffer, and dehydrated. The prostate slices then were embedded in Epon. Ultrathin sections were cut with a Reichert-Jung Ultracut E (Nussloch, Germany) and examined with a Phillips CM 12 (Phillips, Eindhoven, The Netherlands).

\section{Immunohistochemistry}

We stained $5 \mu \mathrm{m}$ thick sections cut from archival tissue blocks with a cocktail of mAbs KA 12 (cytoskeletal staining) and Ki 67 (nuclear staining) using biotinylated secondary antibodies followed by visualization with avidin-biotin-conjugated horseradish peroxidase, diaminobenzidine substrate (LSAB 2 kit; Dako, Carpinteria, CA) and hematoxylin counterstain (Fan et al., 1997).

\section{Quantitation of cytokeratin 6a expression and proliferation}

We performed the quantitation of cytokeratin 6a expression and its correlation with Ki 67 expression by using the Ariol SL-50 (TM) system(Applied Imaging Corp, San Jose, CA), an automated scanning microscope and image analysis system. We quantified 407 fields in seven archival cases of normal human prostate tissue, and 327 fields in six fresh cases cultured for $72 \mathrm{~h}$ using the prostate organ culture model. The cases in the prostate organ culture model were not identical with the adult cases. Randomly selected fields from both transitional and peripheral zones were scanned at $20 \times$ magnification. Glandular epithelia were carefully selected with a freehand tool to exclude stromal cells from the count. No distinction was made between cytokeratin 6 a expression in basal and luminal cells for this analysis. In the prostate organ cultures, no distinction was made between cytokeratin 6a expression in the newly formed surface epithelium and pre-existing glands within the tissue slice. For quantitation of Ck6a+ cells, the cytoskeletal staining was scored using the system's Aesight (cytoskeletal) assay. For quantitation of co-expression of cytokeratin 6a with Ki 67 or Ki 67 alone, the areas analyzed 
for cytokeratin 6a expression were reprocessed with the Kisight assay (morphometric nuclear detection).

\section{Statistics}

In regards to distribution and proliferation of Ck6a+ cells, we used the unpaired $t$-test to determine the statistical significance of difference between the adult normal prostates and the prostate organ culture model. For determining the correlation between cytokeratin $6 \mathrm{a}$ distribution and proliferation index we calculated the Pearson's correlation coefficient $(r)$ followed by testing the significance ( $p$-value).

\section{Results}

\section{Specificity of monoclonal antibody KA 12 for cytokeratin 6a}

We assessed the specificity of mAb clone KA 12 for human type II cytokeratin 6a by twodimensional Western-blotting in human hair follicle and vaginal mucosa, both tissues known to express cytokeratin 6a (McGowan and Coulombe, 1998). In both tissues, mAb clone KA 12 recognized specifically cytokeratin $6 \mathrm{a}$ and did not cross-react with cytokeratin 5 (Fig. 1a and b) or any other cytokeratin present (Fig. 1a and b). Another study also showed the specificity of mAb clone KA 12 for cytokeratin 6a (Langbein et al., 2003).

\section{Cytokeratin 6a expression in prostatic primary epithelial cells}

Upon culturing prostatic tissue pieces an outgrowth of proliferation-competent epithelial cells occurs (Fig. 1c) that express basal cell-specific cytokeratin 5 (not shown). Immunostaining with mAb KA 12 showed the presence of cytokeratin 6a in these primary cells forming a typical intermediate filament network (Fig. 1c). In all primary cell samples analyzed, a protein band with a molecular weight of $\sim 56 \mathrm{kDa}$ corresponding to that one of cytokeratin $6 \mathrm{a}$ was recognized by mAb KA 12 (Fig. 1d) indicating that cytokeratin 6a is expressed by prostatic epithelial cells (Ck6a+ cells).

\section{Cytokeratin 6a expression in the fetal and juvenile human prostate}

We examined cytokeratin 6a expression in the fetal and juvenile human prostate. At 22 weeks gestation, we found cytokeratin 6a abundantly expressed in the urogenital sinus and in the developing bladder (Fig. 2a). In some glandular cross-sections cytokeratin 6a was expressed focally in single cells or in cell clusters in both the basal and luminal layers (Fig. 2a). Some sections were completely cytokeratin 6a negative. At weeks 33, 34, and 39 of gestation (Fig. $2 \mathrm{~b}$ and $\mathrm{c}$ ), the prostatic glandular epithelium showed a cytokeratin 6a expression pattern similar to week 22 of gestation. In addition, in all gestation stages we observed Ck6a+ cells located in the mesenchymal stroma both adjacent and distant to glands (Fig. 2b-d). The mesenchymally located Ck6a+ cells were negative for laminin 5, an extracellular matrix protein confining the differentiated gland (Fig. 2d). In juvenile glands, prior to puberty, we found cytokeratin $6 \mathrm{a}$ expression in single cells as well as in small-to-large cell clusters (Fig. 2e-g). In the juvenile cases we did not observe mesenchymally located Ck6a+ cells. These data indicate that the $\mathrm{Ck6a}+$ cells reside in specialized niches in both fetal and juvenile prostates with a spectrum from sparse to abundant occurrence.

\section{Cytokeratin 6a expression in adult normal human prostatic glands}

In adult normal prostatic glands, $\mathrm{Ck6a}+$ cells were predominantly located within the cytokeratin 5-positive basal cell compartment in both the transitional and peripheral prostatic zones (Fig. 3a). Here, the Ck6a+ cells occurred focally either in cell clusters (Fig. 3a) or as single cells (Fig. 3a). In many $4 \mu \mathrm{m}$ thick glandular cross-sections the Ck6a+ cells were not observed. Immunohistochemical analysis of serial sections revealed that the Ck6a+ cells 
occurred in "niches" characteristic for stem cells (Fig. 3b). By double staining with chromogranin A we found the Ck6a+ cells to be distinct from neuroendocrine cells (Fig. 3c).

\section{Differentiation potential of cytokeratin 6a-positive cells}

While uncommitted stem cells reside in the basal cell layer, it is expected that a differentiation signal stimulates a relocation of stem cells within the glandular epithelium. We observed some Ck6a+ cells extending from the basal compartment to the lumen, a characteristic ascribed to prostatic stem cells. Cytokeratin 19-positive cells were suggested to play a key role in prostatic epithelial cell differentiation (Hudson et al., 2001). As expected, we observed, that Ck6a+ cells that were localized in the basal layer did not co-express cytokeratin 19 (Fig. 3d). In contrast, Ck6a+ cells that were moving to the luminal layer co-expressed cytokeratin 19 (Fig. 3d), indicating that these cells were committed for differentiation. However, not all cytokeratin 19positive luminal cells co-expressed cytokeratin $6 \mathrm{a}$ (Fig. 3d). This is consistent with a dynamic phenotype characteristic for stem cells. We observed three populations of Ck6a+ cells by triple staining of cytokeratin $6 a$ with the hemidesmosomal marker $\alpha 6$ integrin and the tight-junctional protein ZO-1, which is solely expressed by terminally differentiated luminal cells in the prostatic gland (Fig. 4a), again indicating the dynamic distribution expected for stem cells. First, Ck6a+ cells were restricted to the basal layer and expressed $\alpha 6$ integrin (Fig. 4a). Second, trans-epithelial Ck6a+ cells extending from the basal layer to the lumen co-expressed both $\alpha 6$ integrin and ZO-1 (Fig. 4a). Third, Ck6a+ cells were observed in-between the luminal and basal layer, which were negative for ZO-1 and $\alpha 6$ integrin (Fig. 4a). Triple staining of cytokeratin 6a with ZO-1 and cytokeratin 5 revealed two types of trans-epithelial cells (Fig. $4 \mathrm{~b}$ ). The first type co-expressed cytokeratin 6a, cytokeratin 5 and ZO-1 (Fig. 4b). The second type co-expressed only cytokeratin 5 and ZO-1 (Fig. 4b). These data imply that Ck6a+ cells can differentiate into luminal cells.

\section{Proliferation and amplification potential of cytokeratin 6a-expressing cells}

In the actively proliferating epithelia of the developing human fetal prostate, we observed a considerable number of Ck6a+ cells co-expressing Ki 67 (Fig. 4c). In the slow cycling adult prostatic glandular epithelium a few proliferating cells expressed cytokeratin 6a (Fig. 4c, Table 1a). A 'Prostate Organ Culture Model' was recently described in which the presence of growth factor-enriched serum stimulated cytokeratin 5-positive basal cells to proliferate as well as migrate from cut open glands to the culture surface to form and cover the stroma with a new surface epithelium (Parrish et al., 2002). We determined if the Ck6a+ cells were the cell type that responded to this 'wound/tissue repair' signaling. Prior to culturing the tissue slices (Day 0 ), the Ck6a+ cells exhibited the same restricted niche-like distribution pattern as in the normal adult prostate (Fig. 5a). Subsequently on Day 1, 2 and 3 of culturing, we observed a remarkable increase of $\mathrm{Ck6a}+$ cells with some glands showing all basal cells co-expressing cytokeratin $6 \mathrm{a}$ along with cytokeratin 5 (Fig. $5 \mathrm{~b}$ and c). On Day 3 , glands located within the tissue slice showed up-regulation of cytokeratin 6a expression across the entire gland (Fig. 5c, Table 1a). The newly formed surface epithelium expressed cytokeratin 6a (Fig. 5c), and formed ultrastructurally a new basement membrane (not shown) with deposition of the extracellular matrix proteins laminin 5 and collagen VII (Fig. 5b,c). This new surface epitheliumalso showed differentiation into luminal and basal cells as shown by prostate specific antigen (PSA) expression (Fig. 5d) and by conventional electron microscopy (Fig. 5e). Here, some basal cells showed short tonofilaments indicating a rudimentary squamous differentiation (not shown). The up-regulation of cytokeratin 6a expression coincided with the onset of proliferation as shown by double staining with Ki 67 (Fig. 5f).

Quantitation of cytokeratin 6a and Ki 67 expression in adult normal prostate (Table 1a) showed that the average number of Ck6a+ cells was $4.9 \%( \pm 3.7 \mathrm{SD})$. Here, the proliferation index was $1.1 \%$ ( $\pm 0.8 \mathrm{SD})$ with $3.79 \%( \pm 4.0 \mathrm{SD})$ of proliferative cells expressing cytokeratin 6 a. In 
contrast, in the prostate organ culture model the average number of Ck6a+ cells was $64.9 \%$ $( \pm 18.7 \mathrm{SD})$. The proliferation index was $5.83 \%( \pm 6.7 \mathrm{SD})$ with $98.76 \%( \pm 1.9 \mathrm{SD})$ of proliferative cells expressing cytokeratin $6 \mathrm{a}$. The difference in cytokeratin $6 \mathrm{a}$ expression between adult normal prostate and the prostate organ culture model was statistically significant $(p<0.0001$; Table 1a). Although we observed a distinct increase in the number of proliferating cells in the prostate organ culture model, the difference in proliferation rate compared to the adult normal prostate was statistically not significant ( $p=0.9552$; Table 1a). The difference in numbers of proliferative cells expressing cytokeratin 6a between the two experimental groups analyzed was statistically significant $(p<0.0001$; Table 1a).

No correlation between numbers of Ck6a+ cells and proliferation index was found within the slow cycling adult normal prostate $(r=-0.0508 ; p=0.9239$; Table 1a). In contrast, within the normal prostate organ model the increase of Ck6a+ cells significantly correlated with the increased proliferation index $(r=0.7616 ; p=0.0467$; Table 1a).

In summary, our data indicate that the Ck6a+ cells can be stimulated to proliferate and differentiate consistent with a transient amplifying cell population.

\section{Discussion}

We have discovered a new epithelial cell phenotype within human prostatic glands. We propose that Ck6a+ cells are prostatic stem cell candidates. Six lines of evidence support this hypothesis: (1) the presence of Ck6a+ cells in fetal, juvenile and adult prostatic glands; (2) the niche-like distribution pattern; (3) the abundance in the fetal urogenital sinus enriched in stem cells; (4) the differentiation potential; (5) the proliferation potential; and (6) the amplification potential of these Ck6a+ cells.

The critical importance of cytokeratin filaments to the resilience and function of epithelia has been established by the discovery of naturally occurring cytokeratin mutations in various diseases (McGowan and Coulombe, 1998; Owens et al., 2004). The members of the cytokeratin 6 family have been associated with chronic hyperproliferative disorders of the skin as well as in carcinomas of urinary bladder, esophagus and other epithelia (McGowan and Coulombe, 1998).

The fetal urogenital sinus, which gives rise to the urinary bladder and to the prostate, is enriched in stem cells. The normal human prostatic ductal morphogenesis, partially regulated by sonic hedgehog (Barnett et al., 2002), occurs in two separate periods, prenatally and pubertally (Cunha et al., 1987; Kellokumpu-Lehtinen et al., 1980; Lowsley, 1912). We identified Ck6a+ cells in the urogenital sinus, in fetal and juvenile prostatic glands, and in the fetal stroma. This suggests a major role of this cell phenotype in prostatic morphogenesis to be determined in future studies.

The distribution pattern displayed by Ck6a+ cells as observed in this study is consistent with stem cell niches (Chepko and Dickson, 2003). Investigative studies in other epithelial systems strongly support a model in which stem cells must reside "on channel" in specialized niches that provide an essential balance of regulatory cell types and factors. This strategically placement of the stem cell enables it to coordinate its function of cell division, differentiation and migration in accordance with the needs of the organ system and to respond to environmental signals for tissue remodeling (Bjerknes and Cheng, 1999; Oshima et al., 2001; Spradling et al., 2001).

Putative prostatic stem cells are expected to express pp32, prostate stem cell antigen, GSTP-1, p63, CD 133, and higher levels of telomerase and $\alpha 2$-integrin, and low levels of p27kip ${ }^{1}$ (Collins et al., 2001; DeMarzo et al., 1998; Moskaluk et al., 1997; Paradis et al., 1999; Reiter 
et al., 1998;Walensky et al., 1993). Future experiments are needed to determine if and under which stimuli Ck6a+ cells express these gene products.

Classically defined stem cells have a capacity to generate daughter cells that can differentiate into several cell lineages to form all the cell types that constitute the mature epithelium (Smalley and Ashworth, 2003). A stem cell might go through an asymmetric cell division to generate one cell that is identical to itself and one cell that is distinct. The identical cell provides maintenance of the stem cell compartment. The distinct cell goes through a series of cell divisions and differentiation steps to generate the terminally differentiated cell populations (Smalley and Ashworth, 2003). Consistent with this concept, we demonstrated that Ck6a+ cells were able to co-express cytokeratin 19 or ZO-1. ZO-1, a tight junctional protein (Sawada et al., 2003), is only expressed by terminally differentiated luminal cells but not by basal cells in the normal adult prostate. This suggests that the Ck6a+ cells that co-express ZO-1 are transient amplifying cells that are committed for terminal differentiation, and which later may lose cytokeratin $6 \mathrm{a}$ expression. This further indicates that cytokeratin $6 \mathrm{a}$ expression may be maintained beyond the stem cell stage. Cytokeratin 19, which has been implicated in the differentiation of many epithelial tissues in which there is a transition between different phenotypes (Stasiak et al., 1989), was also shown to be a marker for prostatic intermediate cells and to play a key role in prostatic differentiation (Hudson et al., 2001).

Epithelial stem cells that are responsible for tissue damage repair are inactive until stimulated (Smalley and Ashworth, 2003). The stem cell compartment can expand and new stem cells can be established within a tissue by symmetric cell divisions in which neither daughter cell progresses to produce transit amplifying cells (Smalley and Ashworth, 2003). Stem cell s could also divide symmetrically to give rise to two transit cells, depleting the stem cell compartment (Smalley and Ashworth, 2003). In further studies we need to determine whether this increase in cytokeratin 6a expression is due to an expansion of pre-existing cytokeratin 6a-positive cells or due to induction in initially cytokeratin 6-negative basal cells. Since cytokeratin 6 is also a marker for squamous metaplasia, which can be caused by injury, we also should consider a limited squamous differentiation as partial cause (Bierie et al., 2003) for the dramatic increase of cytokeratin 6 expression in our in vitro model. The stem cell nature again is supported by three facts: (1) The new surface epithelium expresses PSA, which is not expressed by matured squamous cells in prostatic epithelium (Lager et al., 1988). (2) It differentiates into basal and luminal cells. (3) We did not detect fully developed squamous metaplastic cells by electron microscopy.

The proportions of Ck6a+ cells in the entire cell population and in the proliferative population in the low-turnover adult prostate are quite similar suggesting that cytokeratin 6a expression may not be a prerequisite for proliferation. This is in concordance with observations in other in vivo tissues in which cytokeratin 6a expression occurred mainly in postmitotic epithelial cells (McGowan and Coulombe, 1998). In the prostate organ culture model, in which the tissue organization with epithelial-stromal interaction is maintained, the up-regulation of the cytokeratin 6a expression by as yet unknown factors and the increased proliferation rate were correlated. The coring of the prostate gland specimen obtained from radical prostatectomy for tissue slice acquisition for this in vitro study model led to wounding of prostatic glands and stroma, a tissue damage to which a stem cell and the resulting transient amplifying cells would be expected to respond. In support of the latter possibility, cytokeratin 6a expression was shown to be inducible in suprabasal keratinocyte de novo response to wound stimuli in other epithelial tissues (McGowan and Coulombe, 1998; Mahony et al., 2000).

There are two functional types of stem cells (Smalley and Ashworth, 2003). First, stem cells are responsible for tissue renewal such as replacement of terminally differentiated cells as they mature, die or shed from epithelial surfaces. These cells are continually active at a slow rate. 
Second, stem cells are inactive until required to response to environmental stimuli. Such a functional division may be reflected in phenotypic differences between stem cells in tissues. This may explain the two types of transepithelial cells with either cytokeratin 5 expression or cytokeratin 5 and 6a expression that we observed. Another scenario could be that the two transepithelial cell types are in different stages of differentiation with one having cytokeratin 6a expression switched off. If there is more than one stem cell type for different functions, a hierarchical relationship between them is expected.

A large replicative potential and a long life enables stem cells to accumulate multiple mutations over time, which makes them likely candidates for the cells of origin of cancer (Smalley and Ashworth, 2003). In this study, we have morphologically characterized a new cell phenotype in prostate glandular epithelia, which exhibits differentiation, proliferation and amplification potential. The elucidation of the role of this novel cell population and its regulation in prostatic development and prostatic tissue homeostasis will lead to a better understanding of the growth regulation of this gland in both the normal and pathological state. This may greatly facilitate therapeutic advances for the treatment of common prostatic diseases such as prostate cancer and $\mathrm{BPH}$.

\section{Acknowledgments}

We thank Christopher S. Wendel for statistical expertise, Kathy McDaniel, Virginia Clark, Erica Dexter, Mike Pennington, and Celeste Kremer for technical assistance, and Michael R. Kelly for discussions and ongoing support. This work was supported in part by Grants CA-56666, CA 23074 and CA 75152.

\section{References}

Achtstätter T, Hatzfeld M, Quinlan R, Parmelee D, Franke WW. Separation of cytokeratin polypeptides by gel electrophoretic and chromatographic techniques and their identification by immunoblotting. Methods Enzymol 1986;134:355-371. [PubMed: 2434826]

Barnett D, Huang H, Wu X, Laciak R, Shapir E, Bushman W. The human prostate expresses sonic hedgehog during fetal development. J. Urol 2002;168:2206-2210. [PubMed: 12394760]

Bierie B, Nozawa M, Renou JP, Shillingford JM, Morgan F, Oka T, Taketo MM, Cardiff RD, Miyoshi K, Wagner KU, Robinson GW, Hennighausen L. Activation of beta-catenin in prostate epithelium induces hyperplasias and squamous transdifferentiation. Oncogene 2003;22:3875-3887. [PubMed: 12813461]

Bjerknes M, Cheng H. Clonal analysis of mouse intestinal epithelial progenitors. Gastroenterology 1999;116:7-14. [PubMed: 9869596]

Bonkhoff H, Remberger K. Differentiation pathways and histogenetic aspects of normal and abnormal prostatic growth: a stem cell model. Prostate 1996;28:98-106. [PubMed: 8604398]

Bonkhoff H, Stein U, Remberger K. Multidirectional differentiation in the normal, hyperplastic, and neoplastic human prostate. Hum. Pathol 1994;25:42-46. [PubMed: 7508883]

Bui M, Reiter R. Stem cell genes in androgen-independent prostate cancer. Cancer Metast. Rev 1999;17:391-399.

Chepko G, Dickson R. Ultrastructure of the putative stem cell niche in rat mammary epithelium. Tissue Cell 2003;35:83-93. [PubMed: 12747930]

Collins A, Habib F, Maitland N, Neal D. Identification and isolation of human prostate epithelial stem cells based on $\alpha 2 \beta 1$-integrin expression. J. Cell Sci 2001;114:3865-3872. [PubMed: 11719553]

Cunha G, Donjacour A, Cooke P, Mee S, Bigsby R, Sugimura Y. The endocrinology and developmental biology of the prostate. Endocr. Rev 1987;8:338-362. [PubMed: 3308446]

DeMarzo A, Nelson W, Meeker A, Coffey D. Stem cell features of benign and malignant prostate epithelial cells. J. Urol 1998;160:2381-2392. [PubMed: 9817389]

English H, Drago J, Santen R. Cellular response to androgen depletion and repletion in the rat ventral prostate: autoradiography and morphometric analysis. Prostate 1985;7:41-51. [PubMed: 4080651] 
English HF, Santen RJ, Isaacs JT. Response of glandular versus basal rat ventral prostatic epithelial cells to androgen withdrawal and replacement. Prostate 1987;11:229-242. [PubMed: 3684783]

Fan Z, Clark V, Nagle R. An evaluation of enzymatic and heat epitope retrieval methods for the immunohistochemical staining of the intermediate filaments. Appl. Immunol 1997;5:49-58.

Hayward S, Baskin L, Haughney P, Cunha A, Foster B, Dahiya R, Prins G, Cunha G. Epithelial development in the rat ventral prostate, anterior prostate and seminal vesicle. Act. Anat. (Basel) 1996a;155:81-93.

Hayward S, Cunha G, Dahiya R. Normal development and carcinogenesis of the prostate. A unifying hypothesis. Ann. NY Acad. Sci 1996b;784:50-62. [PubMed: 8651606]

Hudson DL, Guy AT, Fry P, O'Hare MJ, Watt FM, Masters JRW. Epithelial cell differentiation pathways in the human prostate: identification of intermediate phenotypes by keratin expression. J. Histochem. Cytochem 2001;49:271-278. [PubMed: 11156695]

Isaacs J. Development and characteristics of the available animal model systems for the study of prostatic cancer. Prog. Clin. Biol. Res 1987;239:513-576. [PubMed: 3309963]

Isaacs J, Coffey D. Etiology and disease process of benign prostatic hyperplasia. Prostate 1989;2:33-50.

Kellokumpu-Lehtinen P, Santti R, Pelliniemi L. Correlation of early cytodifferentiation of the human fetal prostate and Leydig cells. Anat. Rec 1980;196:263-273. [PubMed: 7406220]

Lager DJ, Goeken JA, Kemp JD, Robinson RA. Squamous metaplasia of the prostate. An immunohistochemical study. Am. J. Clin. Pathol 1988;90:597-601. [PubMed: 2459960]

Langbein L, Rogers MA, Praetzel S, Winter H, Schweizer J. K6irs1, K6irs2, and Kirs4 represent the inner root sheath-specific type II epithelial keratins of the human hair follicle. J. Invest. Dermatol 2003;120:512-522. [PubMed: 12648212]

Lowsley $\mathrm{O}$. The development of the human prostate gland with reference to the development of other structures at the neck of the urinary bladder. Am. J. Anat 1912;13:299-349.

Mahony D, Karunaratne S, Cam G, Rothnagel J. Analysis of mouse keratin 6a regulatory sequences in transgenic mice reveals constitutive, tissue-specific expression by a keratin 6 a minigene. J. Invest. Dermatol 2000;115:795-804. [PubMed: 11069616]

McGowan K, Coulombe P. The wound repair-associated keratins 6, 16 and 17. Insights into the role of intermediate filaments in specifying keratinocyte cytoarchitecture. Subcell. Biochem 1998;31:173204. [PubMed: 9932493]

McNeal J. Origin and evolution of benign prostatic enlargement. Invest. Urol 1978;15:340-345. [PubMed: 75197]

McNeal J. Normal histology of the prostate. Am. J. Surg. Pathol 1988;12:619-633. [PubMed: 2456702]

Moll R, Franke W, Schiller D, Geiger B, Krepler R. The catalog of human cytokeratins: Patterns of expression in normal epithelia, tumors and cultured cells. Cell 1982;31:11-24. [PubMed: 6186379]

Moskaluk C, Duray P, Cowan K, Linehan M, Merino M. Immunohistochemical expression of pi-class glutathione S-transferase is down-regulated in adenocarcinoma of the prostate. Cancer 1997;79:1595-1599. [PubMed: 9118044]

Nagle R, Lucas D, McDaniel K, Clark V, Schmalzel G. New evidence linking mammary and extramammary Paget cells to a common cell phenotype. Am. J. Clin. Pathol 1985;83:431-438. [PubMed: 2580429]

Oshima H, Rochat A, Kedzia C, Kobayashi K, Barrandon Y. Morphogenesis and renewal of hair follicles from adult multipotent stem cells. Cell 2001;104:233-245. [PubMed: 11207364]

Owens DW, Wilson NJ, Hill AJ, Rugg EL, Porter RM, Hutcheson AM, Quinlan RA, van Heel D, Parkes M, Jewell DP, Campbell SS, Ghosh S, Satsangi J, Lane EB. Human keratin 8 mutations that disturb filament assembly observed in inflammatory bowel disease patients. J. Cell Sci 2004;117:1989-1999. [PubMed: 15090596]

Paradis V, Dargere D, Laurendeau I, Benoit G, Vidaud M, Jardin A, Bedossa P. Expression of the RNA component of human telomerase (htr) in prostate cancer, prostatic intraepithelial neoplasia, and normal prostate tissue. J. Pathol 1999;189:213-218. [PubMed: 10547577]

Parrish A, Sallam K, Nyman D, Orozco J, Cress A, Dalkin B, Nagle R, Gandolfi A. Culturing precisioncut human prostate slices as an in vitro model of prostate pathobiology. Cell Biol. Toxicol 2002;18:205-219. [PubMed: 12083426] 
Reiter R, Gu Z, Watabe T, Thomas G, Szigeti K, Davis E, Wahl M, Nisitani S, Yamashiro J, Le Beau M, Loda M, Witte ON. Prostate stem cell antigen: a cell surface marker overexpressed in prostate cancer. Proc. Natl. Acad. Sci. USA 1998;95:1735-1740. [PubMed: 9465086]

Richardson GD, Robson CN, Lang SH, Neal DE, Maitland NJ, Collins AT. CD133, a novel marker for human prostatic epithelial stem cells. J. Cell Sci 2004;117:3539-3545. [PubMed: 15226377]

Rouleau M, Leger J, Tenniswood M. Ductal heterogeneity of cytokeratins, gene expression, and cell death in the rat ventral prostate. Mol. Endocrinol 1990;4:2003-2013. [PubMed: 1707130]

Sawada N, Murata M, Kikuch K, Osanai M, Tobioka H, Kojima T, Chiba H. Tight junctions and human diseases. Med. Electron Microsc 2003;36:147-156. [PubMed: 14505058]

Schalken J, van Leenders G. Cellular and molecular biology of the prostate: stem cell biology. Urology 2003;62:11-20. [PubMed: 14607213]

Schmelz M, Cress A, Scott K, Büger F, Cui H, Sallam K, McDaniel K, Dalkin BL, Nagle R. Different phenotypes in human prostate cancer: $\alpha 6$ or $\alpha 3$ integrin in cell-extracellular adhesion sites. Neoplasia 2002;4:243-254. [PubMed: 11988844]

Sherr C. Cancer cell cycles. Science 1996;274:1672-1677. [PubMed: 8939849]

Sherwood E, Berg L, Mitchell N, McNeal J, Kozlowski J, Lee C. Differential cytokeratin expression in normal hyperplastic and malignant epithelial cells from human prostate. J. Urol 1990;143:167-171. [PubMed: 1688457]

Smalley M, Ashworth A. Stem cells and breast cancer: a field in transit. Nat. Rev. Cancer 2003;3:832844. [PubMed: 14668814]

Spradling A, Drummond-Barbosa D, Kai T. Stem cells find their niche. Nature 2001;414:98-104. [PubMed: 11689954]

Stasiak P, Purkis P, Leigh I, Lane E. Keratin 19: predicted amino acid sequence and broad tissue distribution suggest it evolved from keratinocyte keratins. J. Invest. Dermatol 1989;92:707-716. [PubMed: 2469734]

Sun T, Green H. Keratin filaments of cultured human epidermal cells. Formation of intermolecular disulfide bonds during terminal differentiation. J. Biol. Chem 1978;253:2053-2060. [PubMed: 416022]

Takahashi K, Yan B, Yamanishi K, Imamura S, Coulombe P. The two functional keratin 6 genes of mouse are differentially regulated and evolved independently from their human orthologs. Genomics 1998;53:170-183. [PubMed: 9790766]

van Leenders G, Dijkman H, Hulsbergen-van de Kaa C, Ruiter D, Schalken J. Demonstration of intermediate cells during human prostate epithelial differentiation in situ and in vitro using triplestaining scanning microscopy. Lab. Invest 2000;80:1251-1258. [PubMed: 10950116]

Verhagen A, Ramaekers F, Aalders T, Schaafsma HE, Debruyne FM, Schalken J. Colocalization of basal and luminal cell-type cytokeratins in human prostate cancer. Cancer Res 1992;52:6182-6187. [PubMed: 1384957]

Walensky L, Coffey D, Chen T, Wu T, Pasternack G. A novel M(r) 32,000 nuclear phosphoprotein is selectively expressed in cells competent for self-renewal. Cancer Res 1993;53:4720-4726. [PubMed: 7691403]

Xue Y, Smedts F, Umbas R, Aalders T, Debruyne FM, de la Rosette JJ, Schalken JA. Changes in keratin expression during the development of benign prostatic hyperplasia. Eur. Urol 1997;32:332-338. [PubMed: 9358223]

Xue Y, Sonke G, Schoots C, Schalken J, Verhofstad A, de la Rosette J, Smedts F. Proliferative activity and branching morphogenesis in the human prostate: a closer look at pre-and postnatal prostate growth. Prostate 2001;49:132-139. [PubMed: 11582592] 
a

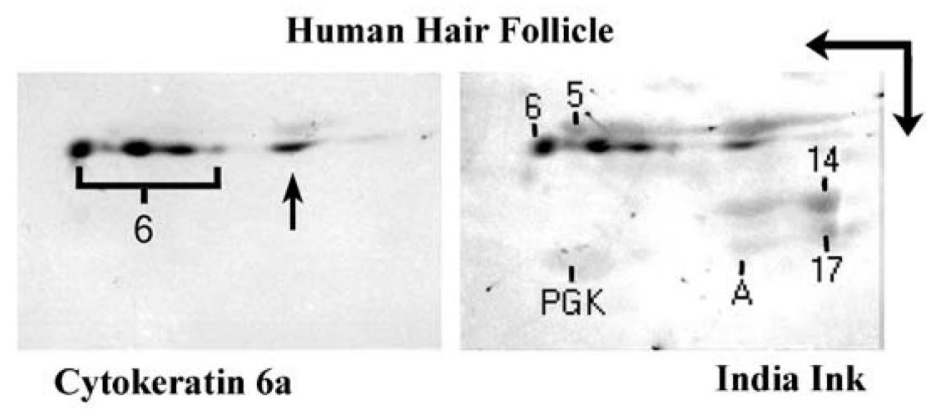

b

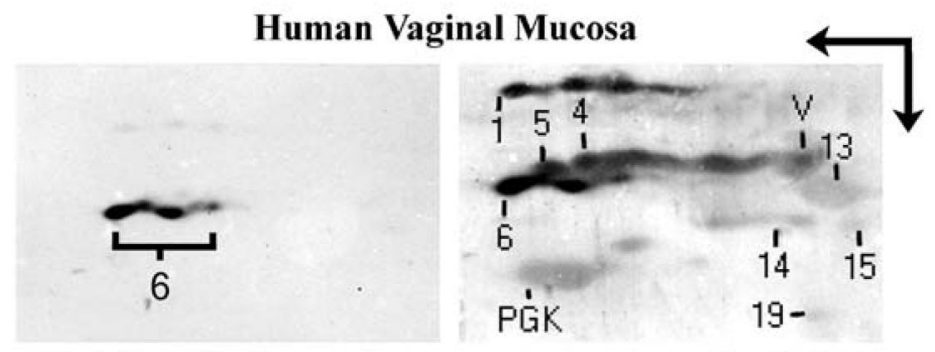

Cytokeratin 6a

\section{India Ink}

c

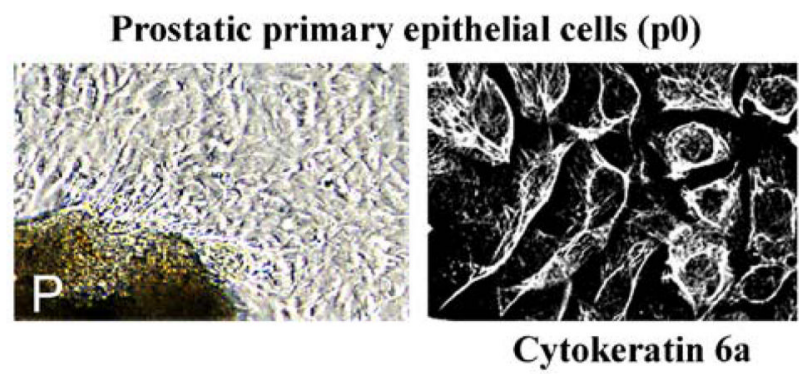

d

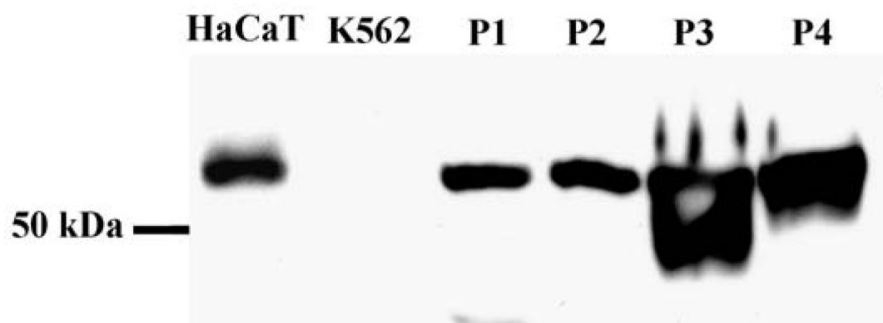

\section{Cytokeratin 6a}

Fig. 1.

Specificity of monoclonal antibody KA 12 for cytokeratin 6a. (a, b) Two-dimensional Western blotting (NEPHGE) of total protein extracts from the outer root sheath of human hair follicle (a) and from the human vaginal mucosa (b) with mAb KA 12. A = endogenous actin, $\mathrm{V}=$ endogenous vimentin, $\mathrm{PGK}=3$-phosphoglycerokinase added as protein marker, Numbers 1 , 4-6, 13-15, 17 and 19 represent cytokeratins 1, 4-6,13-15,17,19 present in the total protein fraction. Double arrows in $(a, b)$ denote the directions of the first dimension (horizontal arrow) and the second dimension (vertical arrow), respectively. Note that mAb KA12 reacted specifically with cytokeratin 6a including its isoelectric variants, and did not cross-react with any other cytokeratins present. The brackets indicate the isoelectric variants of cytokeratin $6 \mathrm{a}$. 
Arrow in (a) denotes minor proportions of cytokeratins migrating in the first dimension as heterodimeric complexes. (c) The left panel shows an outgrowth of primary epithelial cells from a human prostatic tissue piece $(\mathrm{P})$. The right panel shows cytokeratin-specific intermediate filament staining of mAb KA 12 in prostatic primary epithelial cells. Both images were taken at passage $0(\mathrm{p} 0)$. (d) One-dimensional Western blot analysis showing the reaction of mAb KA 12 with cytokeratin 6a expressed in the primary epithelial cells (p0) obtained fromthe prostates of 4 patients (P1-P4). HaCaT cells were used as positive control, and K562 cells were used as negative control. 
a 22 weeks gestation

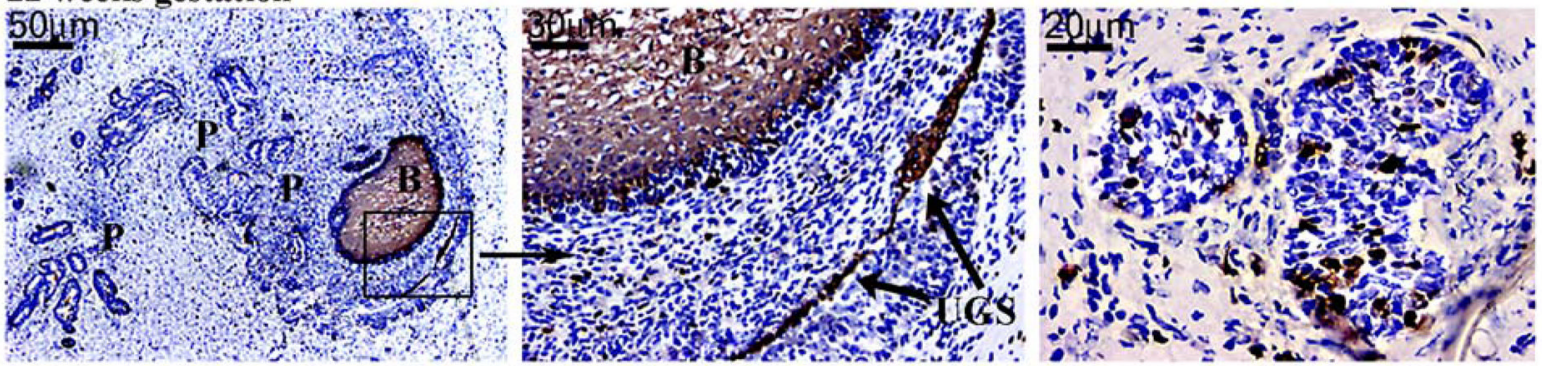

b 33 weeks gestation
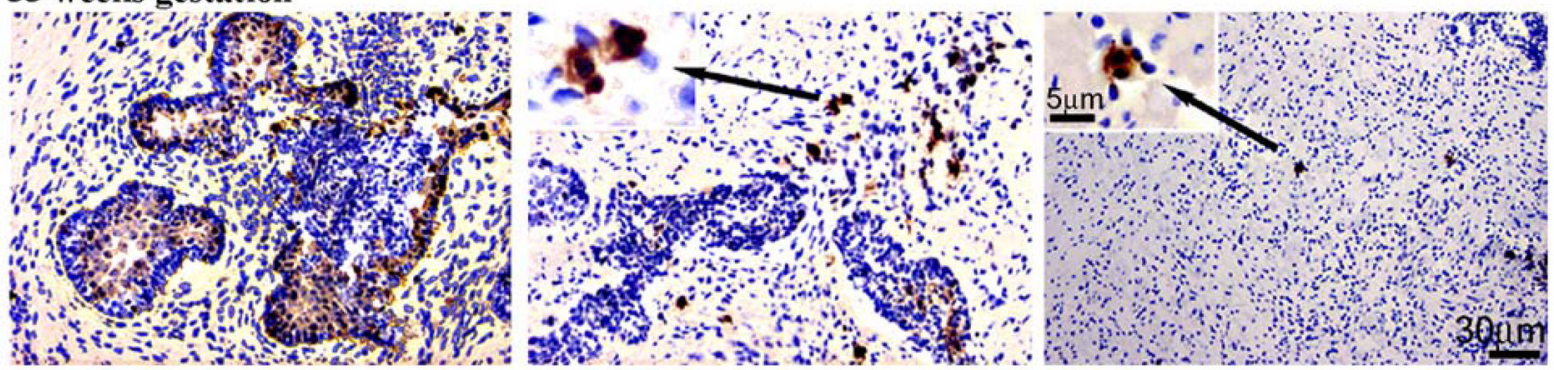

C 39 weeks gestation

d 2 months old (born at 34 weeks gestation)
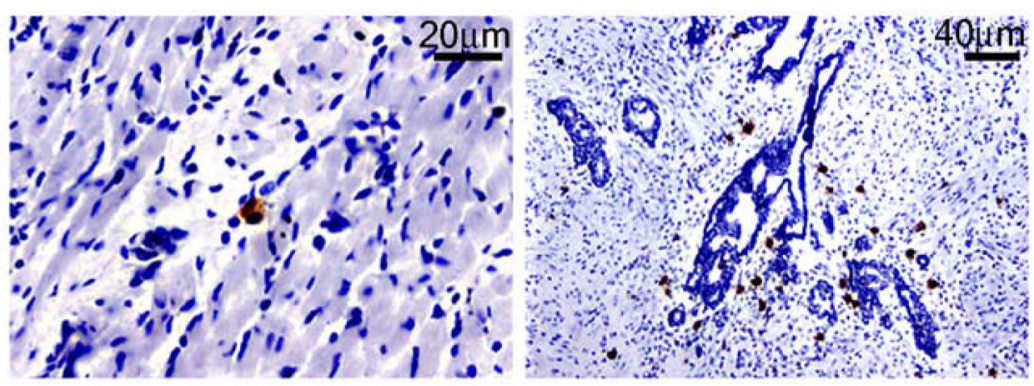

Merge: Cytokeratin 6a + Laminin 5

e 2 years old

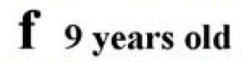

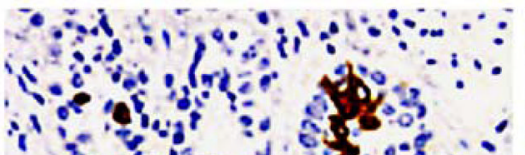
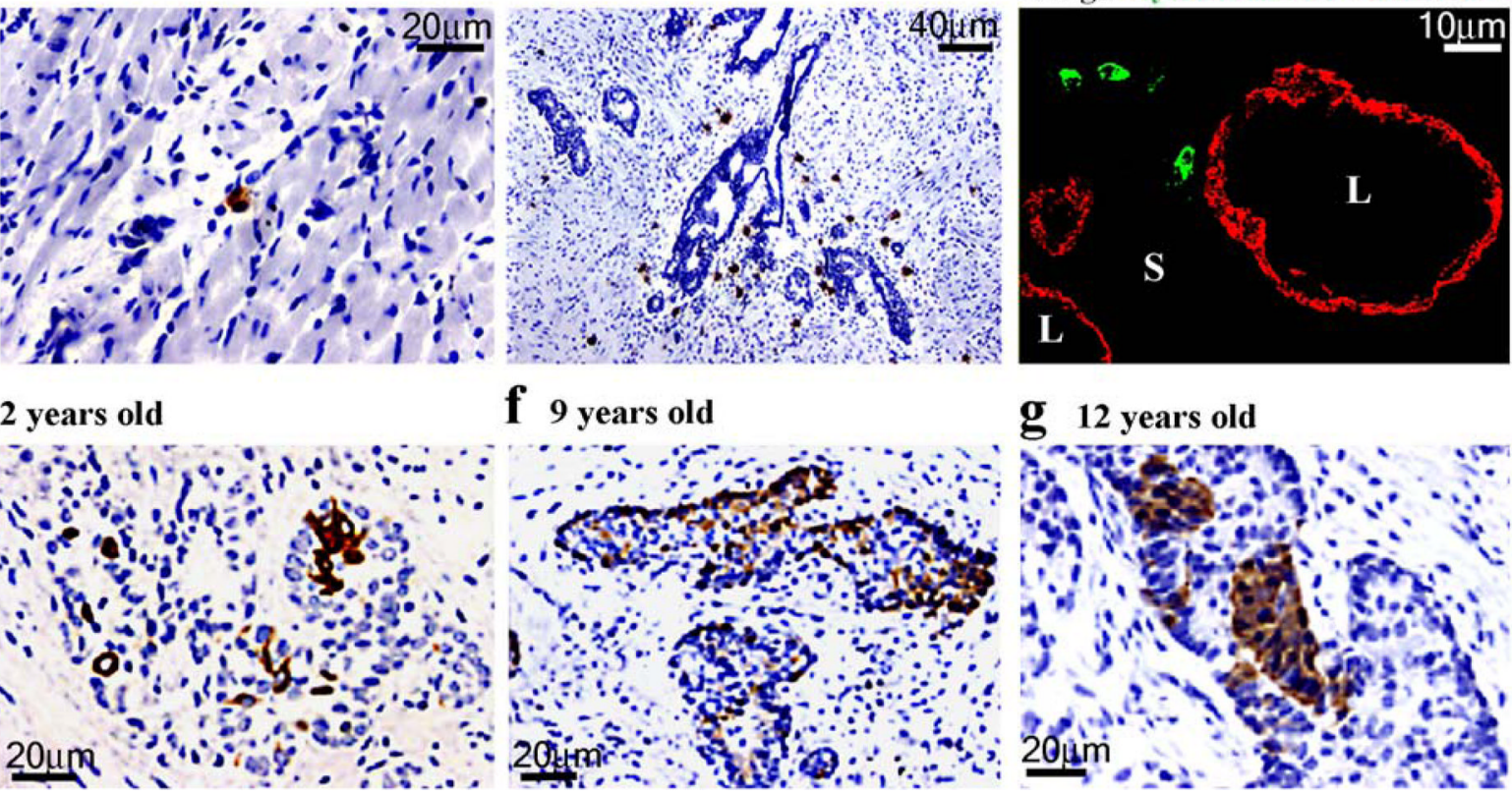

$\therefore$ Ho

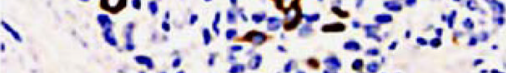

20un

g 12 years old

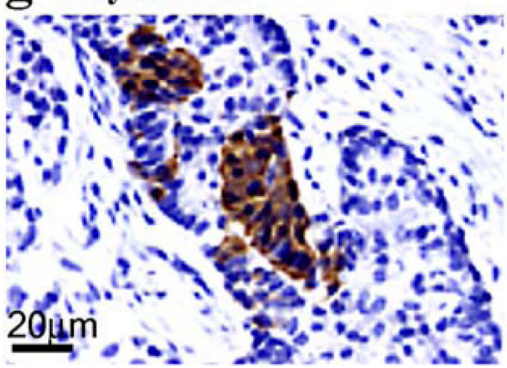

Fig. 2.

Cytokeratin 6a expression in the fetal $(\mathrm{a}-\mathrm{c})$ and juvenile $(\mathrm{d}-\mathrm{g})$ human prostate. (a) The prostatic ductal networks (P) at 22 weeks gestation (left image) are formed by solid epithelial outgrowths that emerge from the urogenital sinus (UGS) below the developing bladder epithelium(B = bladder). The framed area (middle image) and another distinct field with prostatic glands (right image) is shown at higher magnification. The UGS and the bladder epithelium abundantly expressed cytokeratin 6a. Some of the prostatic glandular epithelia expressed cytokeratin 6 in single cells or in cell clusters, whereas other glandular epithelial areas did not show any cytokeratin 6 a expression. (b-c) At 33 (b) and 39 (c) weeks gestation, in addition to the cytokeratin 6 a expression in glandular epithelium (left image), single or small groups of 
cytokeratin 6a-expressing cells were observed in the mesenchyme (middle and right image). Arrows indicate higher magnified fields (insets) of extraglandular cytokeratin 6a-expressing cells. These "extraglandular" cells were either in close proximity to glandular structures (middle image and inset) or distal from these (right image and inset). (d) Two-months old (born at 34 weeks gestation): The left panel shows mesenchymally located cytokeratin $6 \mathrm{a}$ cells in close proximity to a gland, which is cytokeratin 6 a negative. The right image shows doublestaining of cytokeratin 6a (green) with laminin 5 (red). (e-g) Shows cytokeratin 6a expression in the epithelium of juvenile prostatic glands. Cytokeratin 6a expression occurs in clusters or in single cells. 

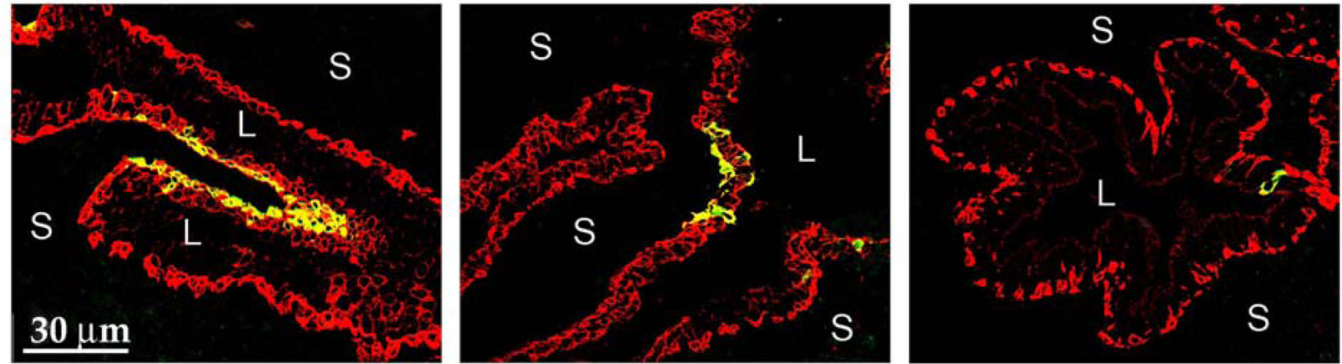

b Cytokeratin 6a expression in serial sections

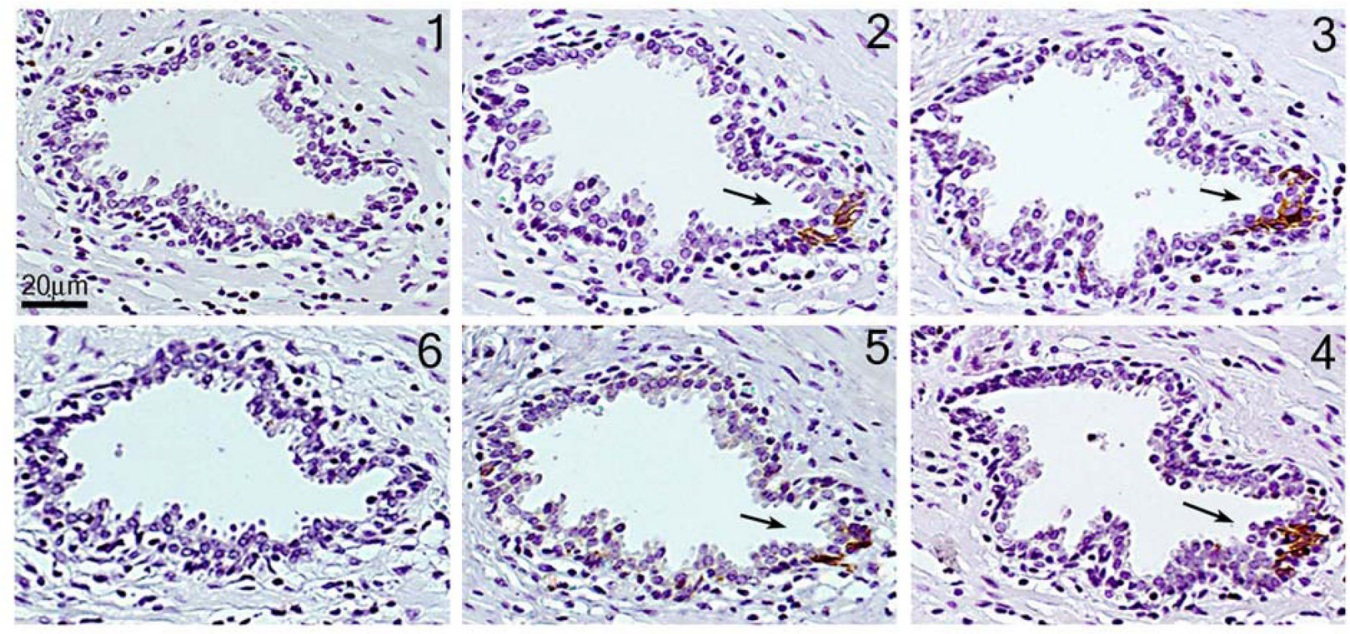

Merge:

Cytokeratin 6a + Chromogranin A

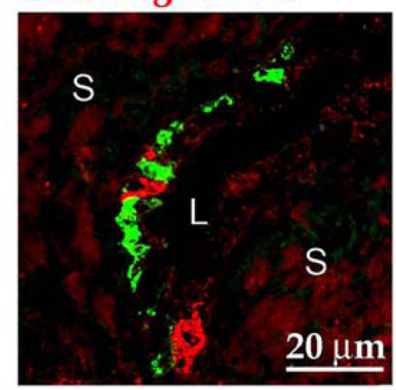

\section{d Merge:}

Cytokeratin 6a

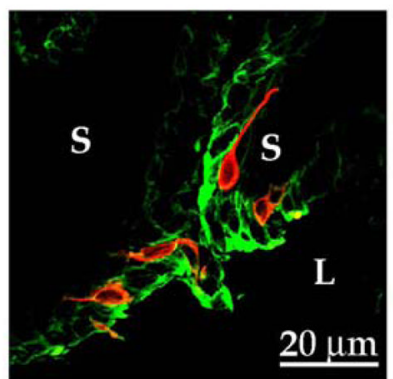

Cytokeratin 19

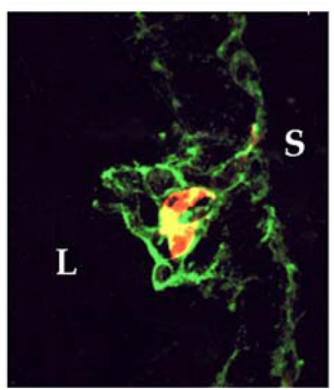

Fig. 3.

Cytokeratin 6a expression in normal human adult prostatic glands. (a) Three representative fields showing the distribution pattern of cytokeratin 6a-positive cells (green) by doublestaining with basal cell-specific cytokeratin 5 (red), which outlines the basal compartment in normal glands. The fainter staining of luminal cells in the red channel is due to some crossreaction with cytokeratins $8 / 18$. Note that most cytokeratin 6a-expressing cells resided in the basal compartment. Co-localization of cytokeratin $6 \mathrm{a}$ with cytokeratin 5 appeared in yellow. (b) Immunohistochemical serial sections of one gland from the peripheral zone showing that cytokeratin 6a expression was restricted to so-called niches (arrows), a stem cell property. (c) Co-localization analysis of cytokeratin 6a (green) and chromogranin A (red) revealed that 
cytokeratin 6a-expressing cells are not identical with neuroendocrine cells. (d) Co-localization analysis of cytokeratin $6 \mathrm{a}(\mathrm{red})$ with cytokeratin 19 (green). Note that there is no co-localization in the one field, whereas the other field shows some co-localization appearing in yellow. $\mathrm{S}=$ stroma, $\mathrm{L}=$ glandular lumen. 

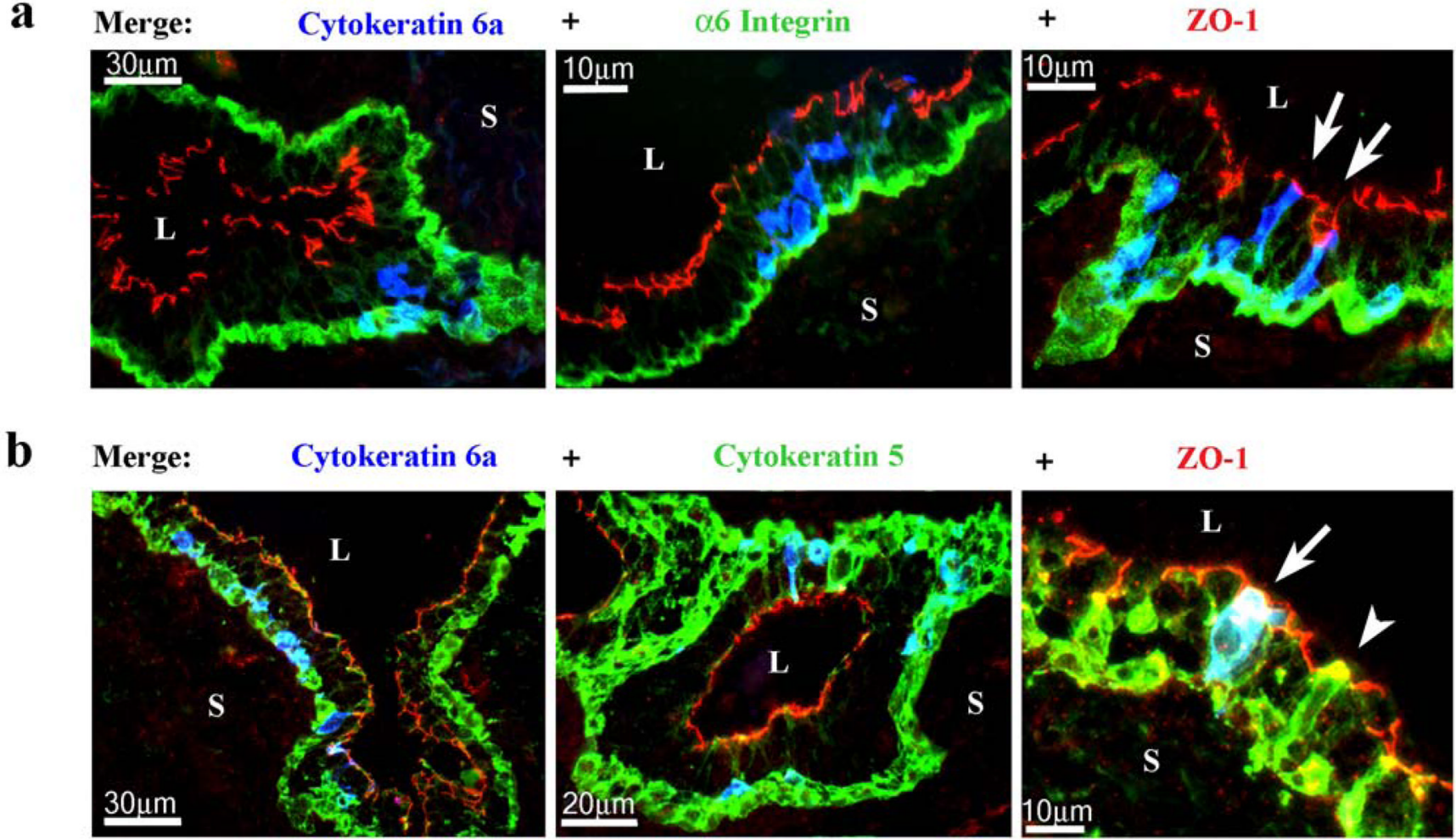

C Merge: Cytokeratin 6a + Ki 67 + nuclear dye

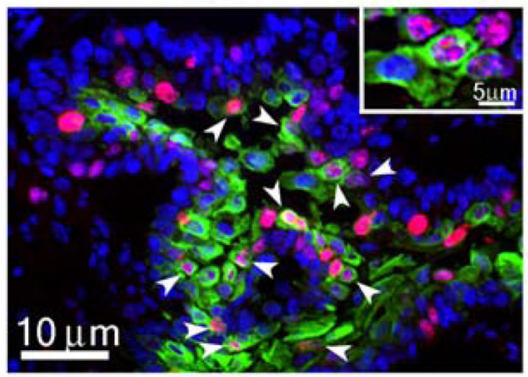

fetal: 34 weeks gestation

\section{Cocktail: Cytokeratin 6a + Ki 67}

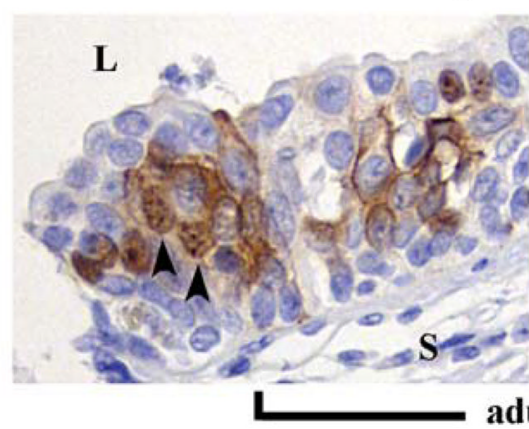

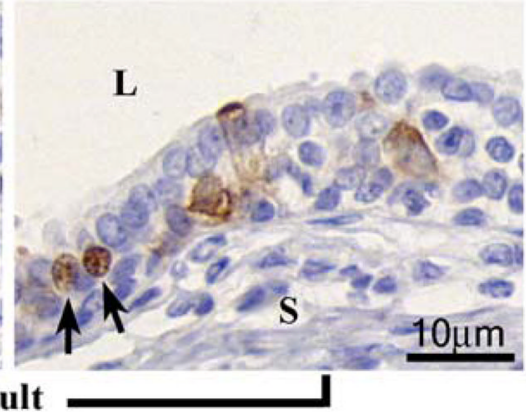

Fig. 4.

Differentiation and proliferation capacity of cytokeratin 6a-positive cells in human normal prostate. (a) Three representative fields showing triple-staining of cytokeratin 6a (blue) with $\alpha 6$ integrin (green) and ZO-1 (red). Note that some cytokeratin 6aexpressing cells co-localized with $\alpha 6$ integrin in the basal compartment and thus appeared in turquoise (or lighter blue), while some other cytokeratin 6a cells also co-expressed ZO-1 (arrows). (b) Three representative fields showing triple-staining of cytokeratin 6a (blue) with cytokeratin 5 (green) and ZO-1 (red). Note that many cytokeratin 6a-expressing cells resided in the basal compartment by co-localization with cytokeratin 5 and thus appeared in turquoise (or lighter blue). A few cytokeratin 6a-expressing cells extended from the basal compartment to the lumen and co-expressed ZO-1 (red) and cytokeratin 5 (green). The overlay of green, red and blue appeared as white (arrow). Some cytokeratin 6a-negative but cytokeratin 5-positive cells also extended from the luminal compartment to the lumen and co-localized with ZO-1 appearing 
in yellow (arrowhead). (c) Triple-staining of cytokeratin 6a (green) with Ki 67 (red) and bisbenzimide H33258 (blue) in the fetal prostate (left image). Here, proliferative nuclei appeared in pink (insets). White arrowheads indicate proliferative cytokeratin 6a-positive cells. Two representative fields (middle and right image) with immunohistochemical staining using an anti-cytokeratin 6a (cytoskeletal) and anti-Ki 67 (nuclear) cocktail are shown for adult normal prostate. Black arrowheads indicate proliferating cells expressing cytokeratin 6a. Black arrows indicate proliferating cells that were cytokeratin 6a negative. $\mathrm{S}=$ troma, $\mathrm{L}=$ glandular lumen. 


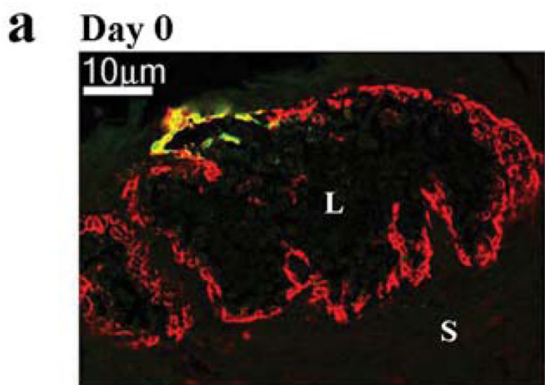

Merge:

Cytokeratin 6a + Cytokeratin 5 Cytokeratin 6a + Cytokeratin 5

b Day 2

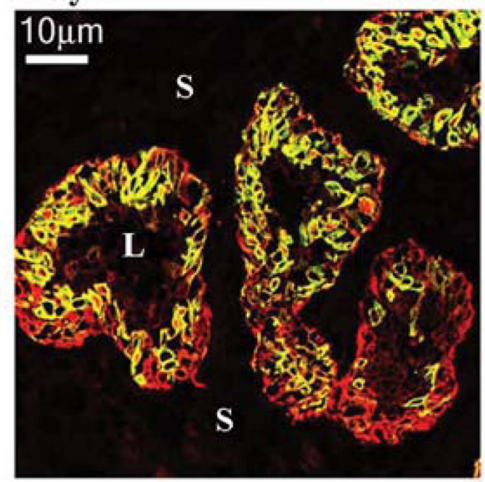

Merge:

Cytokeratin 6a + Cytokeratin 5 Cytokeratin 6a + Cytokeratin 5

c Day 3

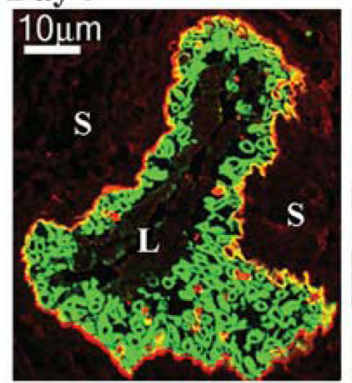

Merge: Cytokeratin 6a + Laminin 5

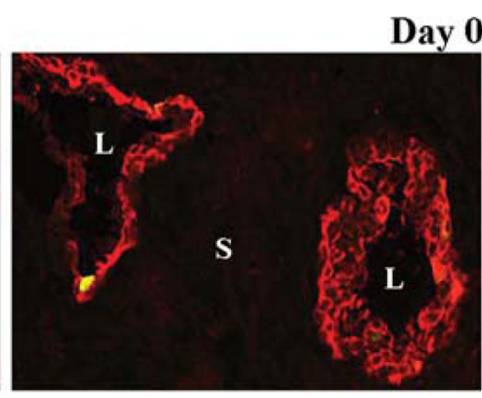

Merge:

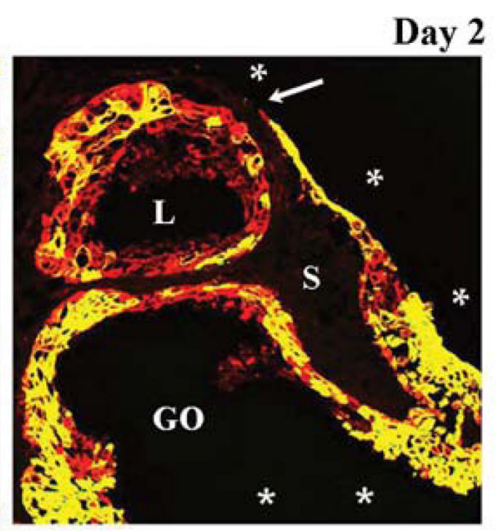

\section{Merge:}

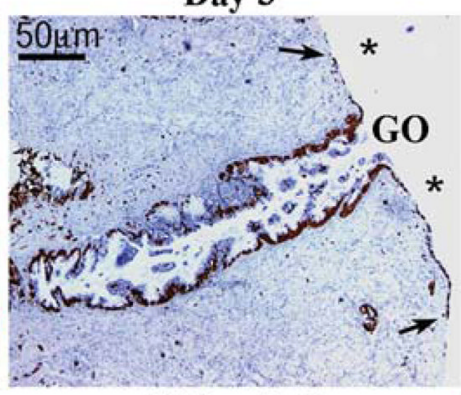

Cytokeratin 6a

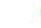

Collagen VII + Laminin 5
Day 3

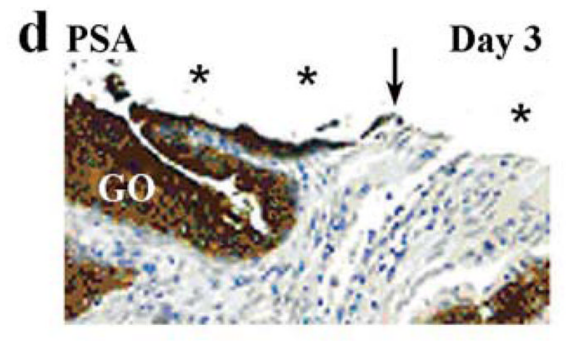

e

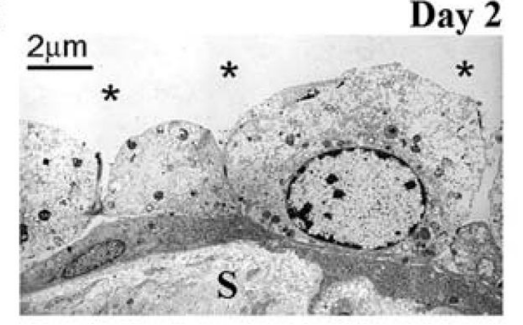

f Day 3

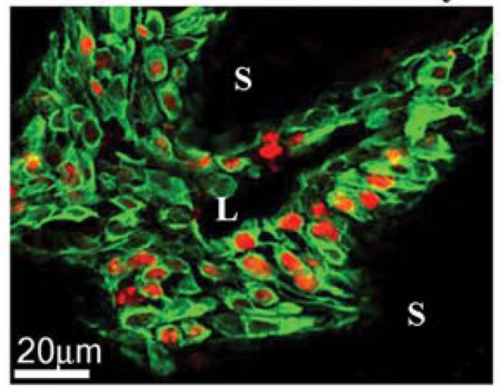

Merge: Cytokeratin 6+ Ki 67

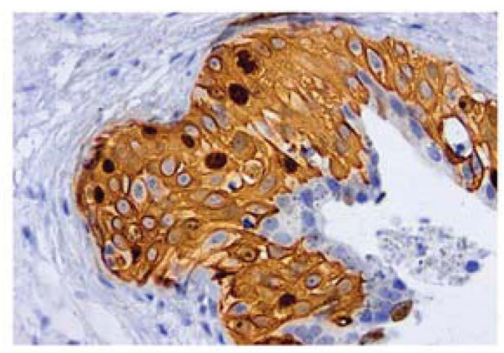

Cocktail: Cytokeratin $6 \mathrm{a}+\mathrm{Ki} 67$

Fig. 5.

Amplification and proliferation potential of cytokeratin 6a-expressing cells. The prostate organ culture model revealed the amplification (a-c), differentiation (c-e) and proliferation potential (f) of Ck6a+ cells. (a) Prior to culturing (Day 0), the cytokeratin 6a expression pattern in the tissue sections is similar to that observed in vivo, as shown in two representative fields. Doublestaining of cytokeratin 6a (green) with cytokeratin 5 (red) revealed a few clusters of Ck6a+ cells in the basal compartment of a few glands. (b) After Day 2 in culture, cytokeratin 6a expression was up-regulated in most glands as shown by double-staining with cytokeratin 5 (red) in two representative fields. Co-localization of these two antigens appeared as yellow.

(c) After Day 3 in culture, most glands (left image) showed an abundant expression of cytokeratin $6 \mathrm{a}$ (green) as shown by double-staining with basement membrane specific laminin 
5 (red). From cut open glands (GO), the Ck6a+ cells migrated to the surface and formed a new surface epithelium $(*)$ as shown in the right image in (b) and by immunohistochemistry in the middle image in (c). Double-staining of laminin 5 (red) and collagen VII (green) showing that the new surface epithelium deposits these two proteins into a new extracellular matrix (right image in (c)). (d) shows PSA expression in the newly formed surface epithelium. (e) Electron micrograph of an area in the newly formed surface epithelium $(*)$ showing differentiation into basal and luminal cells. (f) The up-regulation of cytokeratin 6a expression in this prostate organ model corresponded to the onset of proliferation as shown by double-staining of cytokeratin 6a (green) with Ki 67 (red) at Day 2, and by immunohistochemistry using a cocktail of anticytokeratin $6 \mathrm{a}$ (cytoskeletal) and anti-Ki 67 (nuclear) antibodies followed by visualization with DAB at Day 3. All white and black arrows point to the leading edge of the newly forming surface epithelium. All white and black stars indicate the free surface. $\mathrm{S}=$ stroma, $\mathrm{L}=$ glandular lumen, $\mathrm{GO}=$ gland cut open by coring of the prostatic tissue. 
Table 1

Statistical significance ( $p$-value) of difference (a) and correlation between cytokeratin 6a expression and proliferation index (b)

(a) Distribution of Ck6a+ cells in adult normal prostate tissue and organ cultures

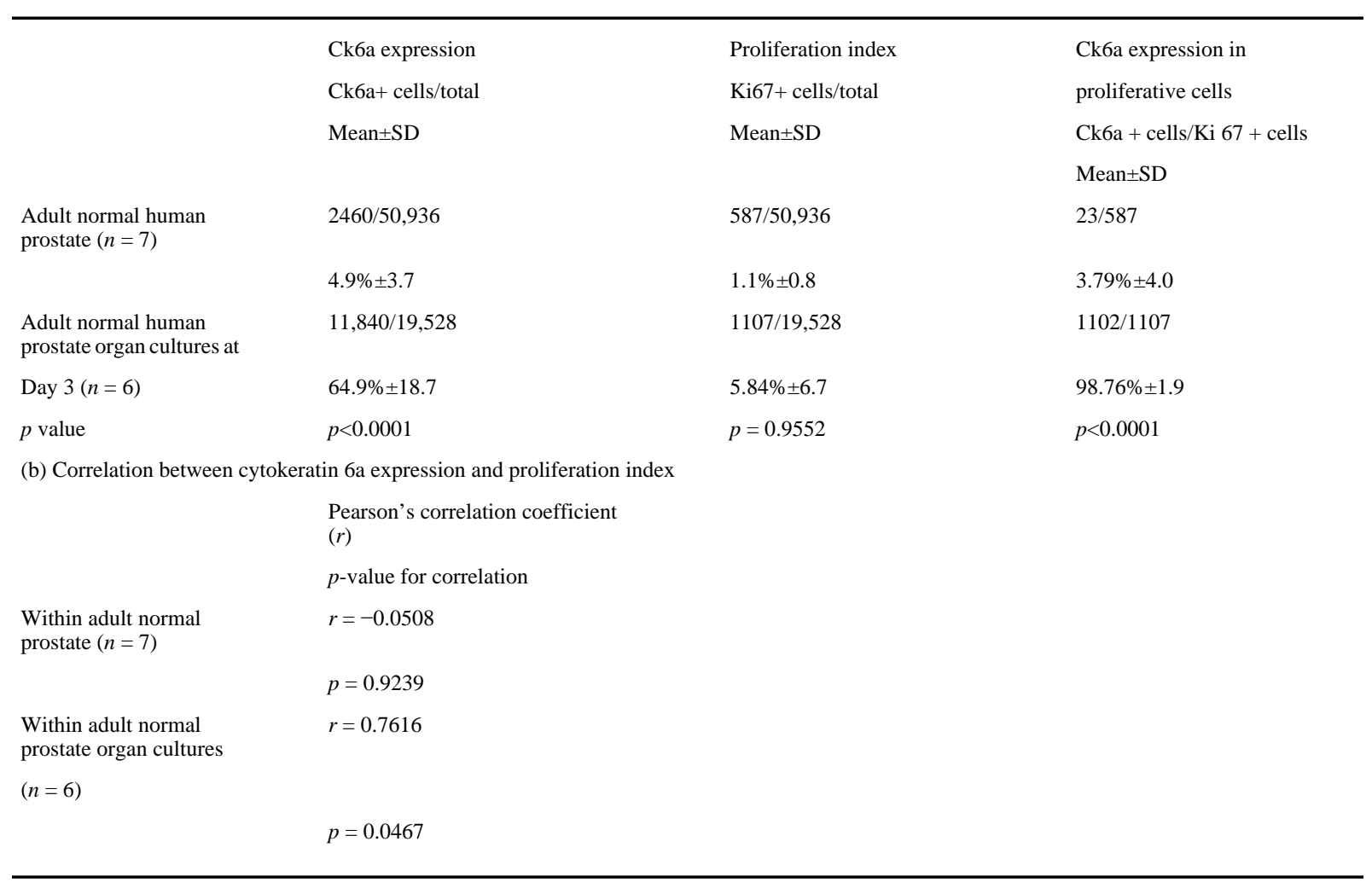

